\title{
Gehan and George Body Surface Area Formula
}

National Cancer Institute

\section{Source}

National Cancer Institute. Gehan and George Body Surface Area Formula. NCI

Thesaurus. Code C68649.

The formula to calculate body surface area as described by EA Gehan and SL George. It is mathematically defined as: BSA $\left(m^{\wedge} 2\right)=0.0235 \times$ Height $(\mathrm{cm})^{\wedge} 0.42246 \mathrm{x}$

Weight $(\mathrm{kg})^{\wedge} 0.51456$ 